No.4 p 5-13

\title{
Growth Potential In Romania's West Region
}

\section{Turnock, D.*}

\section{Abstract}

The West Region is one of the more dynamic areas recognised in 1998 for regional development purposes. However, the growth in Arad and Timis counties contrasts with depression in Caras-Severin and Hunedoara where mine closures have led to high unemployment. There are likely to be tensions between strategies to boost the attractiveness of the main towns and programmes to support the weakercounties where'less-favoured areas' have been declared.

The paper considers these contrasting images of the region and emphasises the need for balance in the interest of regional cohesion. Cross-border cooperation is animportantfeature of regional development and this could be a positive factor in both parts of the region.

Keywords:Romania,WestRegion, growth potential
A important initiative was taken by he Romanian government in 1998 ith the setting up of organisations to coordinate regional development in eight large regions which now serve as the building blocks for EU cohesion policy (Figure 1). Although the constituent counties remain the top-tier units of local government, Romanian social scientists have identified larger functionally- coherent areas polarising around major provincial cities and roughly similar in population (in excess of two million) as the basis for durable economic and social development and international (cross-border) cooperation (Guvernul Romaniei 1997). Each regional development council will include representatives of every urban and rural local government area to determine policy, while thecorrespondingregionaldevelopment agencies (RDA) will formulate and implement the plans. A national council and a national agency will approve EU structural funding and allocate resources from the national regional development fund while providing specialised assistance for individual councils.
Romania has had historic problems over regional development and EU data on per capita GDP scores rate Bucharest at 44 percent of the EU average with the Centre and West at 35 and the other regions tailing down to 26 for the North East (European Commission 1999). Programmes that highlight these differences, without committing sufficient resources to make a significant impact, run the risk of raising expectations that cannot be satisfied. Therefore the planners have been particularly careful to emphasise the variations that exist within regions, demonstrating contrasts between stronger and weaker counties in every region except Bucharest. Hence the new programme is commended in part as a means of limiting the danger of polarised sub-regions through action to combine stronger and weaker counties. "Growth poles located at the border between centre and peripheral sub-regions could play an important role in solving regional problems" (Romboll 1997 p.5). This means addressing unemployment in depressed industrial regions but also assisting agriculture where this is the key to the poverty problem. In this paper the West Region is used to illustrate the opportunities and problems that exist. The region as a whole is doing relatively well and is poised to develop its international relations, but there are also serious problems of unemployment and the internal contrasts are very evident when Caras-Severin and Hunedoara are compared with Arad and Timis (Figure 2).
*DavidTurnock,GeographyDepartment,The University, Leicester LE1 7RH, U.K.

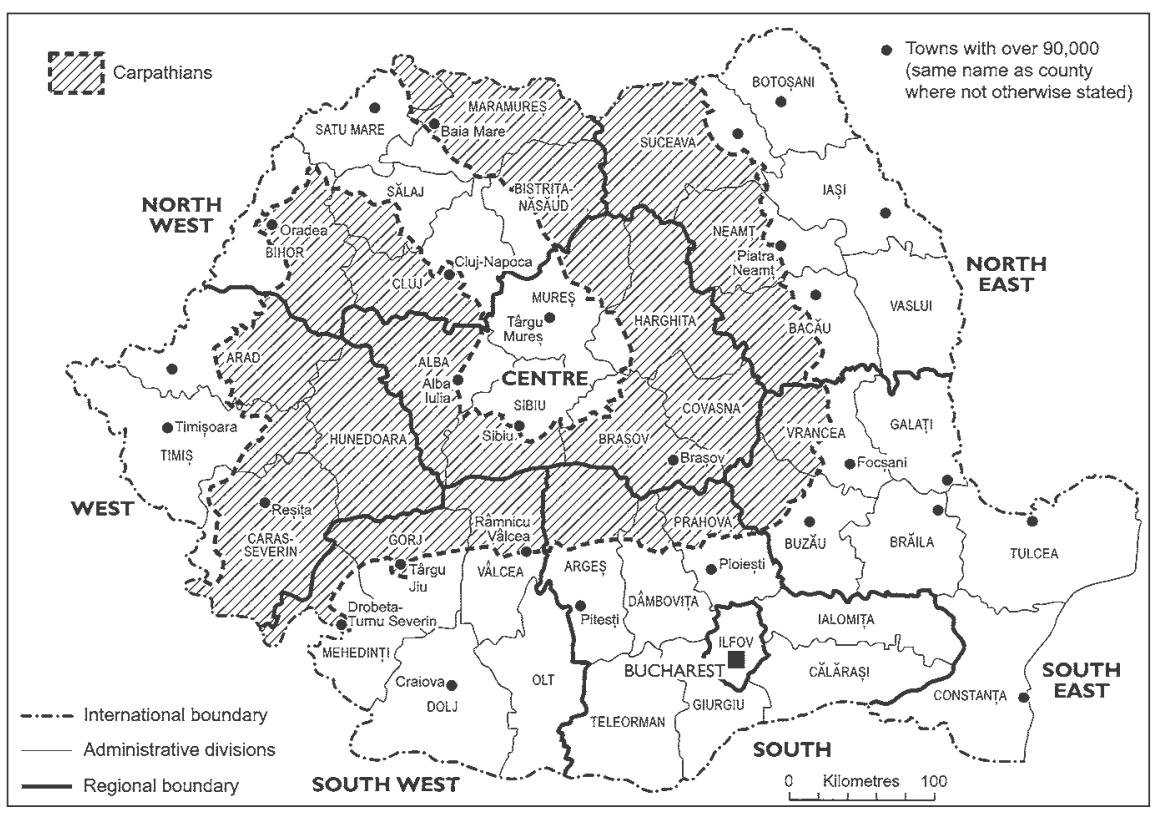

Figure 1: Romania's regional system 


\section{Regional Profile}

The modernisation of the region is based on the Habsburg colonisation of Banat involving diverse ethnic groups which greatly extended a cultural profile based on earlier contacts between Romanians and Hungarians. Although not the region with the largest non-Romanian population, Romanian Banat must be area with the largest number of different non-Romanian ethnic groups. And it is apparent that the experience has been predominantly one of tolerance and mutual respect to the point where all contributions are valued as parts of the region's economic and cultural identity (Popa \& Sarbovan 1999). Nationalism has not significantly detracted from the positive contribution of ethnicity for the human resources of the region. However, the emphasis on agricultural colonisation on the plain was complemented by priority on extractive industries and metallurgy in the mountains. Resita (in Caras-Severin) has a history of ironworking dating back to 1771 (Plate 1) which makes the West one of the longest-established industrial zones in the southeast of Europe: a situation reflected in urban expansion, early electrification, the growth of a relatively dense railway network and the emergence of food processing industries based mainly on the rich agriculture of the Banat Plain. The capacity of the Resita metallurgical and engineering complex to act as a mother factory, stimulating a series of transfers of production to new locations, also indicates the high level of experience and skill.

The historic strength of the extractive industries is extended by consideration of Hunedoara's mineral wealth in coal, in the Jiu Valley at the southern end of the county, complementing the long-established working of non-ferrous ores in the Brad area of the Apuseni

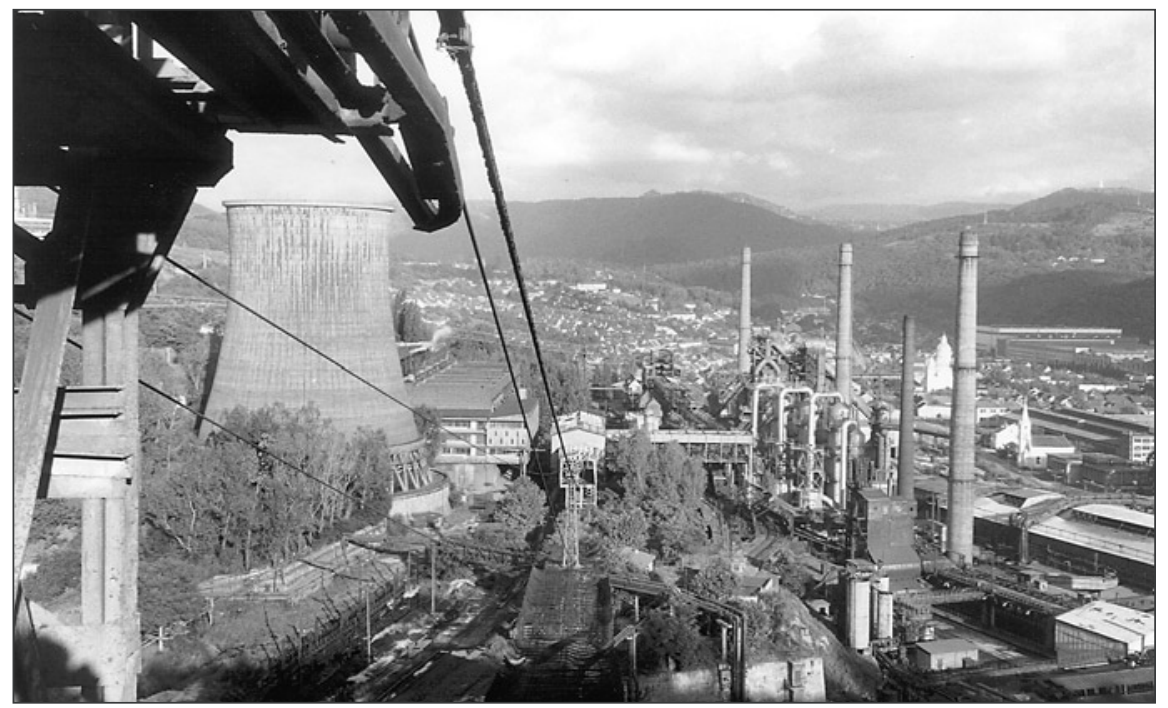

Plate 1: Resita iron and steel works
Mountains to the north. The autarkic stance of the communist regime was conducive to heavy investment in high cost deep-mining ventures which have now been stranded as unviable in the more global market-oriented climate of the last decade. The problems of restructuring are plainly complex and progress can only be sustained if a willingness to reprofile production and boost efficiency is complemented by an inflow of funds and know-how from international financial institutions and foreign direct investors. The West Region has done relatively well with a range of new inter-

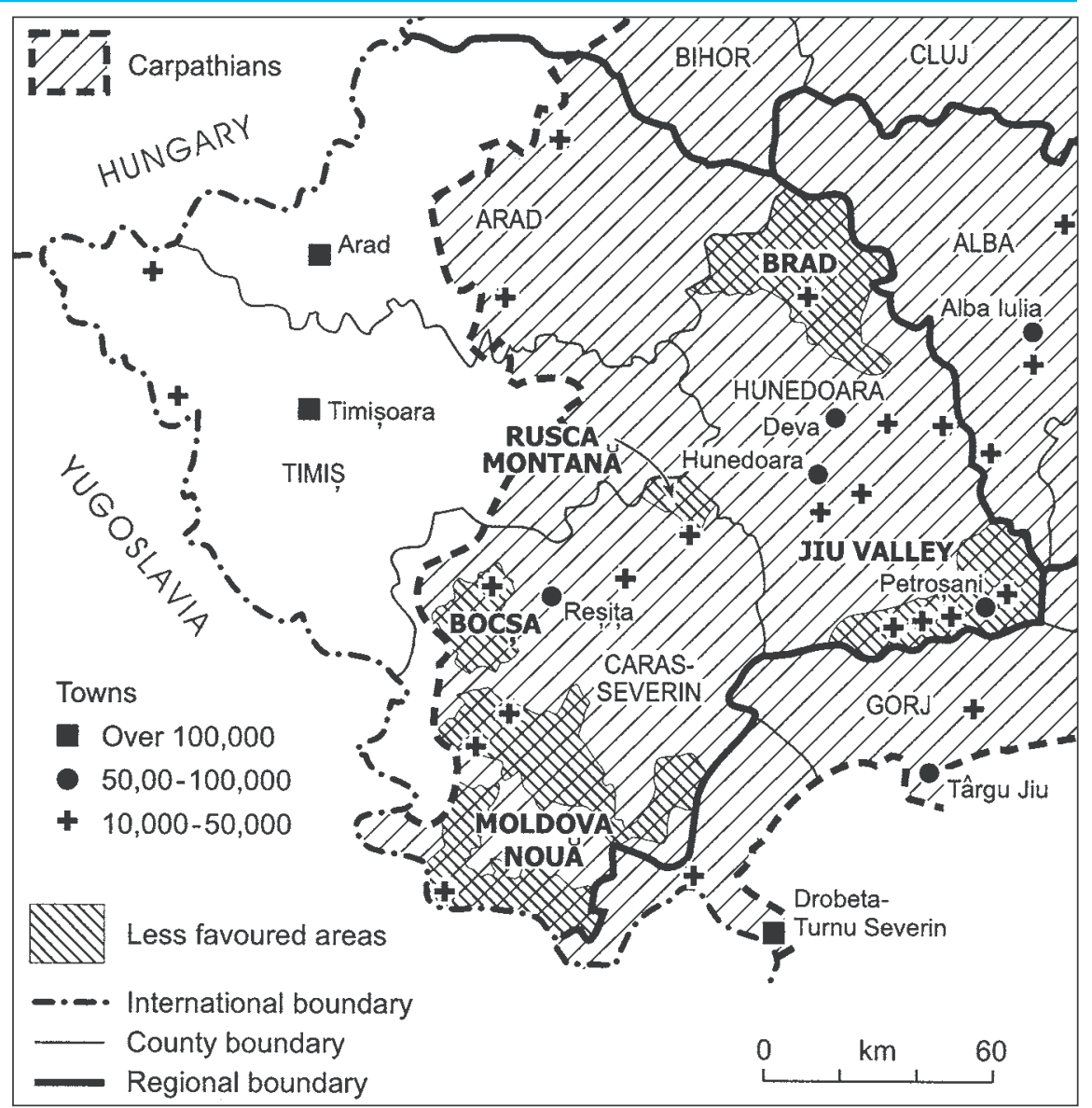

Figure 2: West Regions: towns and less-favoured areas 
Table 1: A Regional Profile

\begin{tabular}{|c|c|c|c|c|c|c|}
\hline Criterion (1995 except where otherwise stated) & $\mathbf{A}$ & B & C & D & $\mathbf{E}$ & $\mathbf{F}$ \\
\hline Per Capita GDP - Thousand ECU Purchasing Power Std. & 5.7 & 4.7 & 6.0 & 7.0 & 6.0 & 5.6 \\
\hline Ditto: Percentage of the EU Average & 23 & 27 & 35 & 41 & 35 & 32 \\
\hline Ditto: CEC Candidate Countries' Average & 78 & 74 & 94 & 110 & 94 & 87 \\
\hline Index of Global Development (a) & 55 & 48 & 58 & 63 & na & na \\
\hline Human Capital Index (b) & 106 & 16 & 57 & 157 & na & na \\
\hline Index of Labour Use (c) & 125 & 15 & 48 & 174 & na & na \\
\hline Share of the Aged Population - 65 years and over & 14 & 12 & 10 & 12 & 12 & 12 \\
\hline Share of Urban Population & 52 & 57 & 76 & 62 & 63 & 55 \\
\hline Urban Population in Cities $100,000+$ inhabitants & 75 & 0 & 0 & 77 & 40 & 57 \\
\hline Participation Rate - Salaries per 1,000 inhabitants & 293 & 260 & 355 & 304 & 307 & 272 \\
\hline Dynamic of Participation 1995 as percent of 1990 & 81 & 66 & 81 & 74 & 76 & 76 \\
\hline Percentage Employed in Industry & 23 & 28 & 44 & 26 & 30 & 29 \\
\hline Percentage of Public Roads Modernised & 24 & 37 & 32 & 21 & 28 & 24 \\
\hline Unemployment Rate & 5 & 10 & 12 & 4 & 0.7 & 10 \\
\hline Infant Mortality (d) & 17 & 21 & 26 & 22 & 22 & 23 \\
\hline Outmigration (e) & 7 & 9 & 10 & 4 & 7 & 0.9 \\
\hline Private cars per thousand inhabitants 1994 & 99 & 95 & 81 & 136 & 106 & 89 \\
\hline Telephone subscriptions per 1,000 inhabitants & 146 & 101 & 104 & 137 & 124 & 129 \\
\hline Culture: Consumption per 1,000 inhabitants (f) & 5.1 & 4.4 & 5.4 & 6.2 & 5.4 & 4.6 \\
\hline Media: Radio \& TV Licences per 1,000 inhabitants (g) & 212 & 175 & 197 & 243 & 212 & 190 \\
\hline Hospital Beds per 1,000 inhabitants & 8 & 8 & 10 & 11 & 9 & 0.8 \\
\hline Water Use: cu. m. per capita & 50 & 51 & 63 & 58 & 56 & 54 \\
\hline Tourist Overnight per 1,000 inhabitants & 3 & 5 & 2 & 2 & 3 & 0.2 \\
\hline Average Criminality Rate 1990-1995 (h) & 253 & 279 & 365 & 343 & 311 & 327 \\
\hline Foreign Investment US\$ per capita 1990-1997 & 52 & 33 & 30 & 180 & 85 & 99 \\
\hline
\end{tabular}

AAradcounty;BCaras-Severincounty;CHunedoaracounty;DTimiscounty;EWestRegion; F Romania

(a) 17indicatorsrelatingtoeconomy,infrastructure,demographyandlivingstandards;(b) basedoneducation,infantmortalityandcommunicationenvironment.Allpositivevaluesare abovethenationalaverage;(c)unemploymentrate,participationrateandout-migration;(d) deathsunderoneyearperthousandlivebirths1993-5;(e)Temporarymigrantstoothercountiesper1,000inhabitants;(f)Sumofsportsmen(tenpercent),thousandcinemaattendance (multipliedbytwo)andthousandlibrarybookslentdividedbytwo;(g)Averageofthetwosets of figures; (h) Convictions per 100,000 inhabitants; Romboll Consultancy Group 1997. Source:ProfilesoftheRomaniandevelopmentregions(Bucharest:RCGforPHAREProgramme, Regional Development Policy) 41-51. Also Eurostat Annex A3; Anuarul Statistic

and the situation is not helped by significant pollution problems in mountain depressions. On the other hand, whereas Arad and Timis have diverse processing industries, with food processing particularly strong. Moreover, "the lowland countryside has been revitalised by reinstatement of private property [helping] farmers increase their revenues, develop local services and intensify the village/town relationship" (Ramboll 1997 p.31). The most impressive indicator however is foreign investment where Timis is more than double the regional average (and nearly double the national average) and six times the level of Hunedoara.

Services are relatively good throughout the region but Timis is outstanding tors in this way, but in view of redundancy many are returning home and "this drain of young labour may create serious long-term development problems" (Ramboll 1997 p.32). Hunedoara scores high for criminality and for infant mortality. Since 1989 there has been much emigration from the region and there has been a sharp decline in the German community: hence rural depopulation despite relatively high living standards in the countryside. There is a net import of population from all other regions of Romania, especially from the North East and North West, but most go to Arad and Timis.

\section{A Strategy For Growth}

Regional plans will inevitably capitalise on the leading assets. Timisoara, the centre of Romania's West Region, can sustain self-reliant internationally -competitive development (Plate 2). With a central location in Timis county and the obvious centre for the region, Timisoara offers qualified labour, education/ training facilities and research institutes (with the university seeking the status of 'centre of excellence'); environmentally friendly industry (at an advanced stage of restructuring) with a stock market, business/exhibition centre and supply networks. It has a network of smalland medium-sized enterprises (SMEs) to serve large enterprises, good banking and local government support, fiscal incentives and low cost sites and premises. Pollution is not a serious problem in view of the bias towards engineering and light industry and services, including waste processing, are relatively modern. It offers institutionalised international relations with Hungary and Yugoslavia, an international airport, a potential shipping lane (Bega Canal) and plans have been drawn up to greatly improve the traffic circulation including the routing of the Bucharest motorway (ADETIM 1998) (Figure 3). The settlement pattern includes strong suburban communities which contribute to the economy through warehousing and industrial sites as well as tourist and recreational facilities.

A new study of Timisoara promotes the city as a growth pole in the context of an expanding Europe and a growing Central European Free Trade Association.

The city could act as a pilot for the adoption of the EU 'acquis' and the process of Romanian integration into the EU generally. An Exhibition Centre and Commercial Park are anticipated as part of a satellite town (Ciuhandu et al. 2000 p.185) which will help to gear up Ti- 


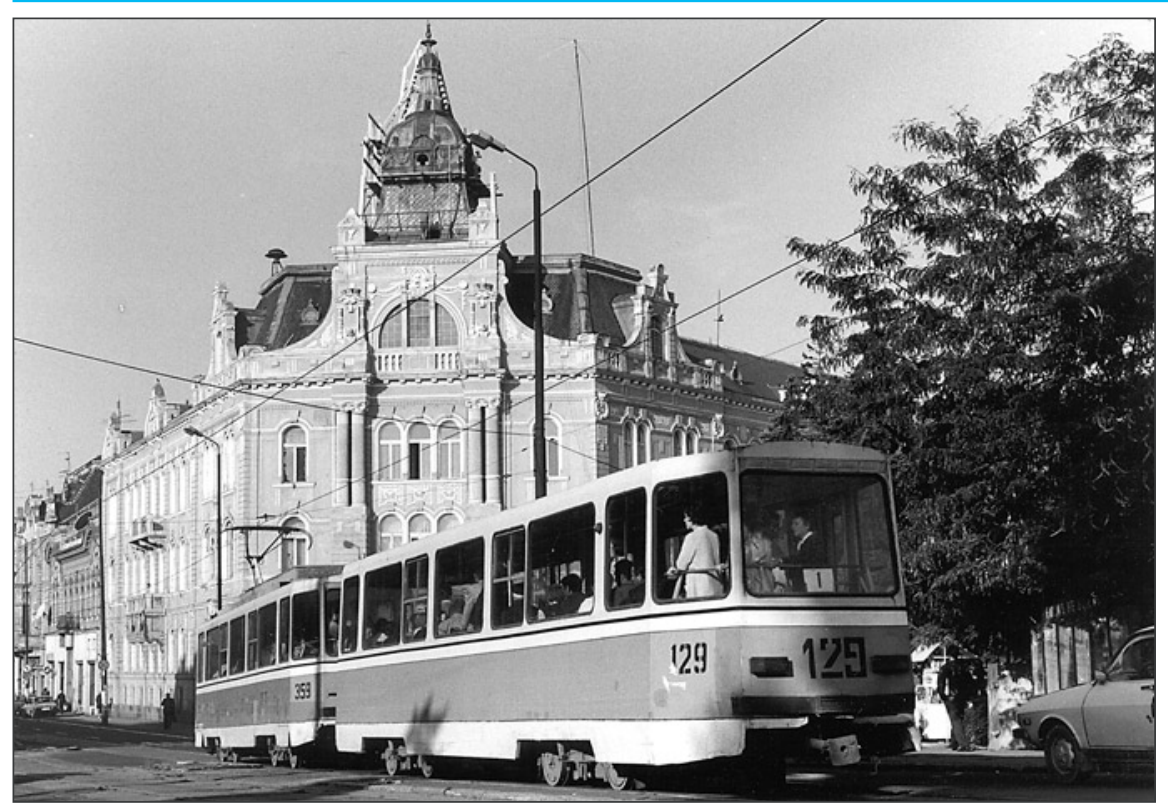

Plate 2: Public buildings in Timisoara: 'Palatul Hidroameliorari Timis-Bega' (1902) now occupied by the regional railway administration

misoara for the creation of 15,000 new jobs during 2000-7 and hopefully a reduction in unemployment from 8.6 to 3.5 percent; plus a boost in average income by 20 percent. However, improvements in local infrastructure and international communications are needed (see below) while the city is constrained by population decline and the emigration of qualified people. The city would like more au- tonomy in education and with higher pay for teachers to retain them for the profession. But there is a fear of renewed centralisation and a 'closed' economy. And an awareness that rapid growth in Timisoara will not be welcome in depressed areas: there will be conflicts of interest both locally in Timis County and more widely across the region. Instability in Southeastern Europe will also have a negative effect, as demonstrated by the Yugoslav War of the early 1990s.

The West Region seeks a restructured agriculture and rural diversification under the guidance of 'Centru Regional de Informare-Comunicare pe Probleme Agricole' and 'Agentia Regionale de Dezvoltare a Spatiu Rural' (Balasa \& Dietzel 1998 p.96). And county plans are supporting such arrangements in respect of small towns and communes with central place functions as centres for non-agricultural functions in predominantly rural area (Coifan 1999 pp.64-5). Integrated local programmes, implemented by SMEs in agriculture, food processing, marketing and tourism (reflecting in part the diversity of ethnic minorities), may be encouraged by an 'Agentia Judetean de Dezvoltare Rurala'. The small town of Deta is seen as suitable location for a specialised livestock market and for fruit processing, including production of a range of brandies, while Faget is seen as a tourist centre for the Poiana Rusca and a suitable location for a small business incubator (generally linked with the larger towns). Each town should also have a 'Club ale Oamenilor de Afaceri'. Stronger rural centres could also emerge at

Figure 3: Planning in Timisoara

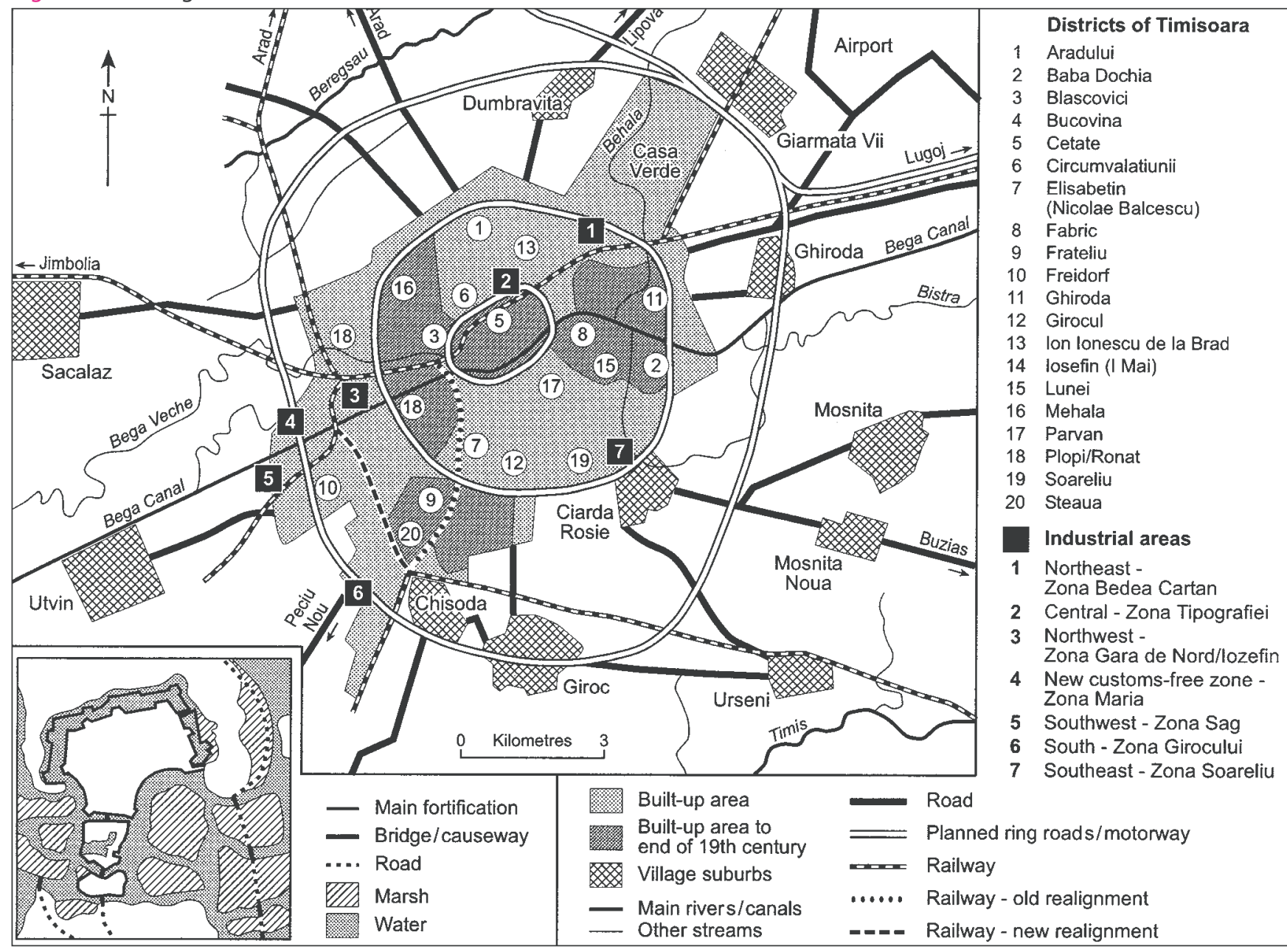


Bethausen, Ciacova, Fardea, Gataia and Recas, although deficiencies in the infrastructure (medical services, natural gas, roads, telecommunications, water and sewerage) are also highlighted. Local halls could be refurbished as multifunctional centres for educational and socialcultural functions (Coifan 1999 p.65) but at Izvin where the high cost of transport into Timisoara provides a basis for independent development the hall has been destroyed and the bricks stolen (Voiculescu 1999). The reality is a long way from the ideal prospect of cinema, culture house, general store with repair workshops, swimming pool, children's park and new school yet the community feels largely powerless.

\section{Less-Favoured Areas}

However, regional development is being linked with 'firefighting' in areas of high social risk, especially in areas of mining rationalisation (Nica 1999). According to arrangements made during 1998-9, the government is recognising less-favoured areas - LFAs ('regiuni defavorizate') which will benefit from fiscal concessions for 3-10 years, to stimulate enterprise, where the unemployment rate is 25 percent higher than the national percentage, a single industrial branch accounts for over half the salaried population working in industry; where massive lay-offs (due to the liquidation, restructuring, or privatisation) affecting more than a quarter of the active population permanently domiciled in the respective areas; and where the area lacks an adequate infrastructure. New enterprises (whether trading companies - with majority private capital, family associations or individuals) may then be exempted from profits tax and all taxes on imported equipment, buildings, transport and land. West Region is much involved in this programme. In Hunedoara county, where problems arose in connection with Brad (nonferrous ores) and the Jiu Valley (coal), two LFAs were created in 1998. And

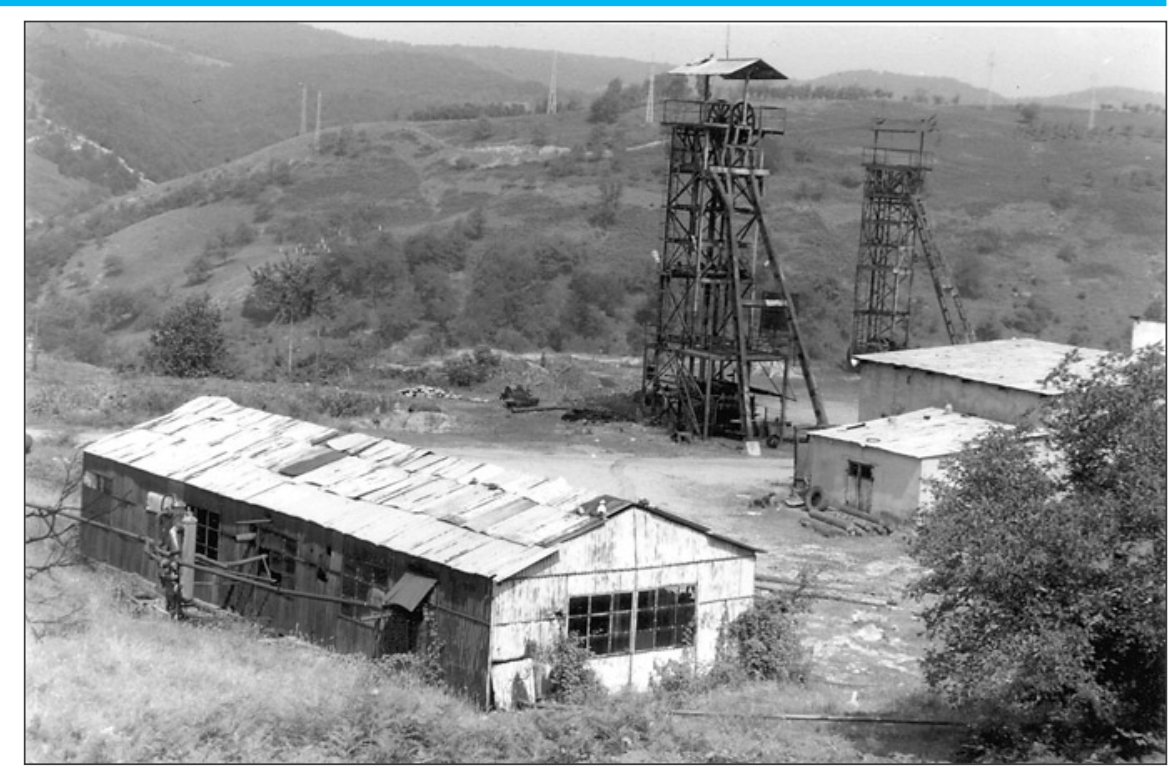

Plate 3:The collieryatLupac:one of many extractive industries to close in Caras-Severin County.

in Caras-Severin county mine closures affected Anina (coal), Bocsa (iron ore), Moldova Noua (non-ferrous ores), Ruschita (lead-zinc) and Sasca Montana (copper) (Plate 3). Accordingly the relevant areas were grouped into LFAs, covering Bocsa, Moldova Noua and Rusca Montana in 1999. Up to the end of March 200084 certificates were issued to allow fiscal concessions in respect of $5687.2 \mathrm{mln}$.lei (Table 2).

The Jiu Valley in the southern part of Hunedoara County constitutes a major problem. It is Romania's most important area of pitcoal production, but demand is falling and imported coal is cheaper. So the government has been making heavy cut-backs, combined with relatively generous redundancy terms and attempts to introduce alternative employment. However the run-down of the industry is deeply resented by a workforce privileged under communism and the miners' attempted march on Bucharest in January 1999 has demonstrated the scale of the opposition. However the five week general strike left the mines in an extremely bad condition and a viable industry is still a long way off. Meanwhile, diversification is under way. Be- fore the revolution some attention was given to the food processing and textile industries, although well-paid jobs for men reduced the demand for female employment. But now a professional training and reconversion centre is operating and a business consulting service is also being provided in Petrosani by a local foundation established in 1997 for the promotion of SMEs and supported by the UN Development Programme and the local business community. Recent research has looked into the coping strategies for redundant workers and progress made in retraining and small business creation; highlighting the need for confidence building in the creation of partnerships and the need for small incubators and subsidised credits (Larionescu et al. 1999).

LFA status has attracted $5204.1 \mathrm{~m} / \mathrm{n}$.lei of investment involving 42 certificated projects: 91.5 percent of all the investment in West Region's LFAs and exactly half the projects. Very prominent is the Lupeni cigarette factory of 1998: a DM7.0mln project by Bulgar Tabac/Romned International, using Romanian capital and Dutch/Italian technology. 200 locals (plus 70 key employ-

Table 2: Less Favoured Areas in West Region

\begin{tabular}{|c|c|c|c|c|c|c|c|c|c|c|c|c|c|c|c|}
\hline LFA & A & B & C & D & E & $\mathrm{F}$ & G & $\mathrm{H}$ & I & $\mathrm{J}$ & K & L & M & $\mathbf{N}$ & 0 \\
\hline Bocsa & 4.99 & 286.2 & 25.0 & 9 & & 8 & 1 & 7 & 2 & & 104.4 & 52.4 & 11.4 & 5.9 & 55 \\
\hline Brad & 12.98 & 1318.4 & 52.9 & 18 & & 13 & 5 & 16 & 2 & & 96.0 & 10.0 & 15.1 & 12.1 & 93 \\
\hline Moldova Noua & 4.99 & 1926.2 & 61.9 & 14 & & 9 & 5 & 13 & & 1 & 280.7 & 10.0 & 11.5 & 6.3 & 55 \\
\hline Rusca Montana & 4.99 & 154.4 & 2.2 & 1 & & 1 & & 1 & & & 2.0 & 0.0 & 7.6 & 7.6 & 2 \\
\hline Valea Jiului & 12.98 & 996.0 & 162.6 & 42 & 1 & 24 & 17 & 36 & 5 & 1 & 5204.1 & 0.0 & 17.2 & 19.7 & 151 \\
\hline Total & & 4681.2 & 304.6 & 84 & 1 & 55 & 28 & 73 & 9 & 2 & 5687.2 & 72.4 & n.a. & n.a. & 356 \\
\hline
\end{tabular}

AZonedeclared(monthandyear);BAreaha;CPopulationth;DCertificatesissued;Elnvestmentsintheprimarysector;FDittomanufacturing, energyandconstruction;GDittoservices;HInvestmentsunder10 mlnlei;IDitto10-100 mlnlei;JDittoover100mlnlei;KTotalinvestment(mln lei); L Ditto foreign investment; M Unemployment January 1999; N Ditto April 2000; 0 New jobs created Source: West Region ARD. 
ees from the Targu Jiu cigarette factory) are employed in a modernised two-storey building packing cigarettes imported from Bulgaria, though the firm intends to invest in a tobacco plantation in Gorj which lies immediately to the south. Meanwhile, the storage battery enterprise ('Acumulatorul') is linked with mining industry while the industrial joinery complex ('Fabrica de Tamplarie') uses PVC imported from Italy. Tourism has a good future in view of the Retezat National Park nearby and the planned road link with Baile Herculane which will in itself create many male jobs. Investment is also going into the local water and power systems.

The Brad zone has attracted a number of small manufacturing ventures. A lingerie factory operates with Italian equipment in a former vegetable store in Brad to supply Italian market, while meat processing takes place in a new building in the town. A low technology woodprocessing unit has been installed in an empty building at Lunciou de Jos, producing furniture from laminated panels imported from Italy, while another empty building in Baita produces cosmetics; again using imported materials and low technology. Meanwhile, in Caras-Severin there has been little progress at Rusca Montana although there is considerable potential for working marble at Ruschita quarry dating back to 1886: the stone is attractive and similar to the Carrara stone. In Bocsa the situation is also very difficult because in addition to the closure of the local iron ore mines, the town has witnessed the near total demise of CMB the country's largest producer of metal structures: bridges on transport routes and swing bridges in ports as well as other welded structures for the mining industry and for thermal and nuclear power stations and farm machinery. This is despite quality certification in welding and collaboration with a range of foreign companies as Ansaldo, ChyodaMara, Krupp, MAN Babcock and Mitsubishi. But the situation has not been helped by a large debt of $\$ 3.35 \mathrm{mln}$ arising from goods supplied to an iron ore plant in Krivoi Rog (Ukraine) in 1989-90.

Surplus space is now being used for new investments including a French firm making car parts; an Italian clothing firm; the Mazzolin (Timisoara) print works and individual entrepreneur Florentin Carpanu making aluminium and wood panels. The German Kurt Bluml wood processing firm is linked with an existing enterprise established in 1994 while another unit is concerned with printing ink cartridges (Italian technology) and a jewellery workshop has been set up in a converted apartment. Finally the old state poultry farm 'Avicola' has been perpetuated through a new chicken rearing enterprise using 40 former workers, while another food enterprise is concerned with meat processing, though it has difficulty in getting raw material. Mineral water is being bottled at Calina, Dognecea. Ornamental rocks could support some local economic diversification and there are some $250 \mathrm{mln}$.cu.m reserves of marble at Dognecea and Ocna de Fier. There are also further opportunities in wood processing.

The Moldova Noua area was originally delimited to include Oravita and all the communes between Oravita and Danube, extending eastwards through the Almaj Depression and the Danube Defile to lablanita and Mehadia; also the commune of Ciudanovita to the north of Oravita. However, in order to concentrate the resources in the areas of greatest need. the area was reduced to two separate districts within this zone: Anina and Oravita with Bozovici, Ciudanovita, Mehadia and Prigor; and Moldova Noua, with Berzasca, Carbunari, Coronini, Sasca Montana and Sichevita communes. Oravita. which offers additional fiscal concessions and free professional help, has already diversified with through a Franco-Romanian 'Normarom' enterprise producing garden furniture and a German enterprise producing furniture based on the local beechwood is a possibility. In Anina, which retains a furniture factory and a sawmill in addition to its long established screw factory, an Italian capitalist is interested in opening a sawmill producing for export, an Austrian firm is thinking about a furniture factory and a Maltese entrepreneur is considering a clothing enterprise.

There is less interest in Moldova Noua despite a commitment to the area by the EU and Nordrhein-Westfalen. The aim is to develop the port on copper mine land and then to create a free port. The infrastructure is a problem since the road from Orsova through the Danube Defile is still unsurfaced, though it has the potential to provide a new route from Bucharest to Belgrade, with a frontier post at Socol (Hillinger 1998). Moldova also lacks a rail link although the reopening of the route from lam (near Oravita) to Bazias and extension along the Danube could solve this problem and, at the same time (given modernisation of the line to Berzovia) make it easier for the Resita engineering and met- allurgical works to despatch rails and heavy equipment. The rural areas have also gained little although Ciudanovita has been badly affected by the closure of a uranium mine and is dependent on EU assistance for the national uranium company (CNU) with regard to a unique conservation project involving some 50ha around the mine which are being prepared for agricultural use. An in incentive here is the spare apartment accommodation since many of the workers in the former uranium mine have left the village.

\section{Growth Potential}

Backed by strong political pressure the LFAs have made a modest impact. ARG staff have built up good relations with investors but there have been problems over training, involving the country labour training agency and the local authorities are not always closely involved with projects and may even be ambivalent over making a case for their areas to benefit from the legislation in the first place. Publicity material for CarasSeverin's LFAs has been produced by 'Fundatia pentru o Societate Deschisa' linked with the County Hall ('Prefectura') and the Chamber of Commerce. Opportunities are seen in industry, particularly in food processing, timber and furniture and textiles while agriculture features with regard to livestock rearing, milk production with cereals, fruit growing and viticulture in appropriate areas. 'Inspectoratul Zonal pentru Resurse Minerale Caransebes' is trying to develop interest in mineral resources. These include coal workings which still have reserves: mainly Anina-Ponor which used to produce around $1.0 \mathrm{mln}$.t but also small mines with good quality coal at Baia Noua and Cozla (the latter used to supply Midia power station) and poorer quality brown coal at Bozovici and Mehadia. Reference should also be made to the gold-silver ores at Oravita, the alluvial gold in the Bistra, Nera and Timis valleys, ornamental granite at Toplet, refractory sand at Anina and mineral waters in various locations. These resources are assessed the geological research company 'Formin' of Caransebes. The company concerned with mineral water at Dognecea is considering a further venture at Prednicova in the Minis Valley. It may also be feasible to rework slag heaps in several industrial locations.

\section{Growth Potential In Tourism}

Agrotourism is highlighted linked with mountain scenery and the Danube defile, with particular interest attaching to 
the national parks and protected areas including many natural monuments: the Anina Mountains display karstic forms (reaching 1,160m at Vf.Leordis) and an interesting vegetation which includes Mediterranean species. But there are also links with hunting and cultural/ religious interests (through churches, monasteries and festivals) especially in the context of ethnic diversity. While Romanians and Roma are always predominant - apart from the Croat majority in Lupac, other groups are significant in most communes: 35 in Ocna de Fier (mainly Ukrainians and Germans), 38 in Sasca Montana (Germans and Hungarians), 53 in Mehadia (Hungarians and Germans), 106 in Bozovici (Germans and Hungarians), 664 in Oravita (Germans, Hungarians and 'Sfabi'), 1,948 in Anina (Germans), 2,039 in Bocsa (Germans, Hungarians and Serbs). Apart from campsites in Anina (200 places) and Bozovici's Minis Valley (150), accommodation is not yet substantial: chalets and motels provide 58 places in Sasca Montana, 76 in Bozovici (Minis) and Oravita, 79 in Anina.

The industrial history is greatly undervalued. Oravita railway station is the oldest in Romania 1849, as is the Anina railway (originally extending to the Danube but now only to the Yugoslav frontier at lam) dating to 1853 . The Anina railway could be developed as a major tourist asset with interpretation to cover the phases of construction, the use of horse and locomotive traction, the historic station at Anina (1864) and locomotive depot at Oravita (1898) and some vintage equipment retained at wayside stations (Plate 4). Industrial archaeology also offers substantial opportunity through the remains of the furnace for the non-ferrous metals near Oravita dating to 1857 and other mining legacies in Anina and Dognecea. There is a tourist project in the Dognecea-Ocna de Fier area (inspired by experience at the Wieliecka salt mine near Krakow) to make use of six lakes (including two at Dognecea refurbished in the 1980s), created in connection with the washing and sorting of ore, and an underground transport passage between Dognecea and the former narrow gauge railhead at Ocna de Fier. In Dognecea the local furnace site is available for reclamation: although most of the old buildings are covered by slag, the ruins of one of the furnaces can still be seen (closed in the late nineteenth century in order to concentrate production in Resita). The private Gruescu museum ('Muzeul de Mineralogie Estetica Constantin Gruescu') lies adjacent to Paulus Mine and com-

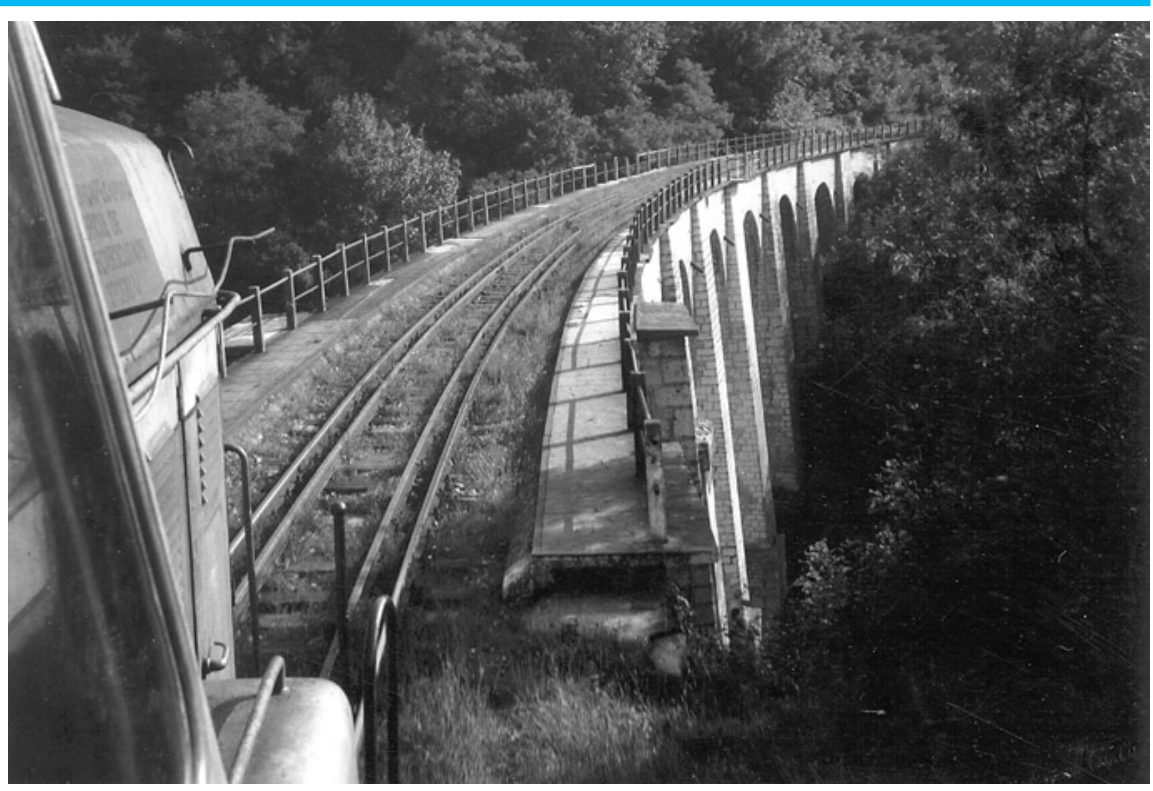

Plate 4: A curving viaduct on the Anina-Oravita railway

prises a remarkable collection of beautiful rocks collected from the local mines.

Oravita also offers the oldest theatre in southeastern Europe: designed by $\mathrm{Vi}$ ennese architect Johann Neumann and built between 1789 and 1817 in a town that was once the centre of Caras County. There are eighteenth century churches: Catholic 1713, and Orthodox 1755 (the latter painted in 1867). The Calugara Monastery was built in 1860-1 and the Town Hall ('Primaria') dates to 1880 (though modified in 1911). Meanwhile, Anina has Roman Catholic churches dating to 1772 (Steierdorf) and 1828 (Anina) while the historic 'Farmacia Steierdorf' now houses a history museum. Finally, Bocsa, lying at a lower altitude of $170 \mathrm{~m}$ in a depression in the Dognecea Mountains offers the ruined Cetatea Cuiesti (a 14th century fortress destroyed by Turks in 1658 - hence the name Buza Turcului). Bocsa has one of the oldest Roman Catholic churches in Romania while Orthodox churches in the area were built in 1755, 1808 and 1815: the most notable is that of Sf. Nicolae, built 1795, painted in 1810 and restored in 1938. Vasiova monastery opened in 1905 and textile workshops were subsequently built during the period 1933-8. When these were taken over by the state in 1959 the monastery closed; but it reopened in 1990 and its important collection of religious books can now be appreciated. Bocsa also has a particular diversity in terms of religion with 14 different cults represented. There is also a rich industrial history is based on the iron furnaces built in Bocsa Montana or Bocsa Vasiovei in 1719 and 1722 the hydropower station (still operating) which was built on the Barzava at the turn of the century.

\section{Extending The Lfa Network}

It is difficult to see how the present scheme can be the 'last word'. In addition to national research initiatives over rural poverty which highlight the Banat Mountaina (Nadejde 1999), West Region has made its own assessments. ADETIM (1998) has pointed to the high unemployment areas east of Lugoj in the Poiana Rusca mountains (and also at Banloc, Ciacova and Satchinez) which require social-economic development programmes based on the local centres, supplemented by cross-border cooperation. However, Coifan's (1999 pp.70-101) 'Programul Strategic de Dezvoltare Economica a Zonelor Defavorizate' refers to a much wider range of problem areas concerned with single industries (Margina, Nadrag and Tomesti); rapid industrial decline (Jimbolia); and backward and remote situations. Reference is also make to areas with heavy depopulation, hazard zones (due to earthquakes, flooding, landslides and pollution) and priority areas for conservation and protection. These proposals take the LFA concept way beyond the present criterion of unemployment into the sphere of road improvement and other infrastructure schemes, though some high unemployment areas like Nadrag (following the closure of the small metallurgical industry 'Ciocanul') should benefit under the current criteria. But progress may be delayed by central government caution (reflecting awareness of the main areas of social risk) and lack of energetic local government support.

\section{Border Regions}

The West Region lies adjacent to areas of Hungary and Yugoslavia which used form part of a unified Banat province under pre-World War One Habsburg 


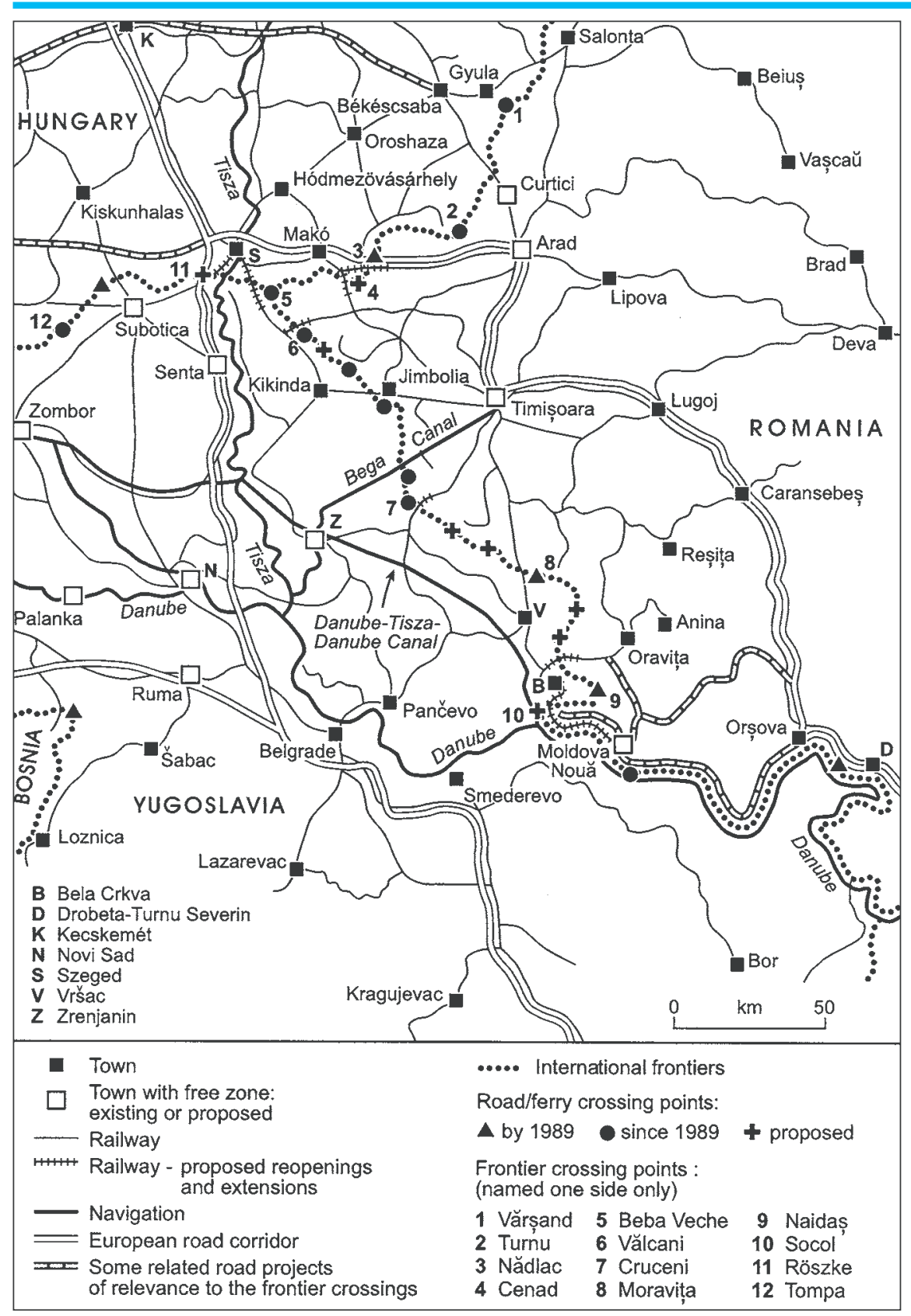

Figure 4: Development proposals in the border region

administration. Now, in the context of an enlarged interdependent Europe there are benefits in developing cohesion. Links between local government in Csongrad (Hungary) and Timis County in 1992 grew by stages into the first version of the protocol for the Euroregion Danube-Cris-Mures-Tisa (DCMT) in 1994 and its final realisation in 1997 with an area of 77,600 sq.kms and a population of $5.2 \mathrm{mln}$ people. It is intended that there should be a coordinated strategy of regional economic development, with a regional commercial centre in $\mathrm{Ti}$ misoara and a greatly improved supply of information coming from a single ' $\mathrm{Di}$ rectorul de Afaceri', although there will also be publications ('Zilele') representing the nine Chambers of Commerce \& Industry (CCls). There will have to be training for young businessmen and efforts to achieve uniform technological standards. There are already forwarding companies in southeastern Hungary, exporting into neighbouring countries as a result of exhibitions organised by the CCls which points to the benefits of the Euroregion in terms of cross-border institutions. Others are needed to organise cultural programmes, including twinning arrangements; the production of tourist maps and media coverage for the Euroregion as a whole (Ciuhandu et al. 2000 pp.28-9).

Border areas in general have been blighted by depopulation and the loss of young people (Ancsin 1999), but Hungarian research suggests that border crossings generate a stimulus for growth (Pal \& Nagy 1999) as commercial activity encourages provision of accommodation and better cultural, medical and leisure facilities as well as a general cleaning up in 'no-man's land'.
There is a desire to improve connections between the largest cities in the three national components - Novi Sad (Yugoslavia), Szeged (Hungary) and Timisoara (Romania) - which are also the second cities in their respective countries. Szeged's rail connections with the other two cities could be greatly improved by restoring the bridge over the Tisza and reopening communication with Kikinda and Subotica along railways dating back to 1857 but closed in 1940 (Figure 4). The Kikinda-Jimbolia section, disused over recent years due to breakdown of services between $\mathrm{Ti}$ misoara and Zagreb during the Yugoslav war, would also have to be refurbished. Other ways of linking Szeged and Timisoara would require restoration of the bridge at Cenad on the Mures or a short overland section at Valcani. However whichever route is preferred it is interesting to note that mending the breach at Szeged and restoring the link eastwards from Subotica towards Baja and Kaposvar in Hungary would provide a new east-west rail route between the Black Sea at Constanta and the Adriatic at Rijeka. Of more local importance is the possibility of restoring the railway between Oravita and Bazias - closed in 1950 - with a possible extension Moldova Noua (already referred to). A rail link between Timisoara and Zrenjanin is also mooted to aid the trickling down of growth to the smaller towns (Tomic \& Romelic 1999).

Meanwhile, the European road corridors will bring big improvements to the Euroregion. Some link roads have already been improved in Hungary and similar works in Romania could greatly improve access in the south where the main highways are presently unsurfaced. Cross-border roads are increasing all the time and many more are proposed. Of great symbolic importance is the new facility at Beba Veche-Kubekhaza-Rabe where the three frontiers merge. Meanwhile the Danube has enormous potential despite the present closure due to NATO bombing of the bridges at Novi Sad during the Kosovo War in 1999. The Tisza is also navigable with a modernised port at Szeged (also a logistical centre with railway 'piggy back' services to Wels in Austria) and there are plans to reopen the Bega Canal (disused since 1958) to Timisoara and establish a customs-free zone: one of several proposed across the region. The problem lies with the lock at Sanmihaiu Roman and the degradation of Pragul Costei, as well as silting and the state of the banks. Finally, the network of regional airports is one of the strengths of the region. In 
Romania, in addition to Timisoara's established role, Arad is seeking international status airports and there are domestic facilities at Caransebes (CarasSeverin) and Deva (Hunedoara) which should boost the prospects of the metallurgical centres of Hunedoara and Resita (Plate 5).

\section{Conclusion}

This paper has attempted to summarise thinking in the West Region about the way to proceed in the present political climate. The region should do well in the future in view of its human resources and infrastructure. There are signs that industrial locations in transition states closer to Western Europe are finding it increasingly difficult to supply the labour required by foreign investors and the result may be a diversion of capital further south and east, as is already evident in Hungary. West Region is evidently seen as attractive by migrants from other parts of Romania, while people who have left Banat for Western Europe in recent years may in some cases be in a position to steer investments in this direction given their own awareness of the region's stability and business record; not to mention the position its position on the European transport corridors which emphasise both the Danube river and corresponding roadrail communications. Yet the region is very much on the margins of Southeastern Europe with a record of insecurity arising in part from in adequate investment in the past. And within West Region there are LFAs which will challenge the aspirations of Timisoara (and to a lesser extent Arad) to attract the lion's share of new jobs. As is the case across Eastern Europe whole, a gulf exists between winners and losers. West Region will have to keep thinking about lifting depression in Bocsa and the Jiu Valley as well as boosting the image of its capital.

\section{References}

ADETIM ed. 1998, Timis County - a

forward looking Romanian county in Europe: social and economical development strategy (Timisoara: ADETIM).

G.S. Ancsin 1999, 'A demographic analysis of the Hungarian and Romanian border settlements on the southern Great Plain' In: C. Gruia et al. eds., Proceedings of the Regional Conference of Geography: Danube-Cris-

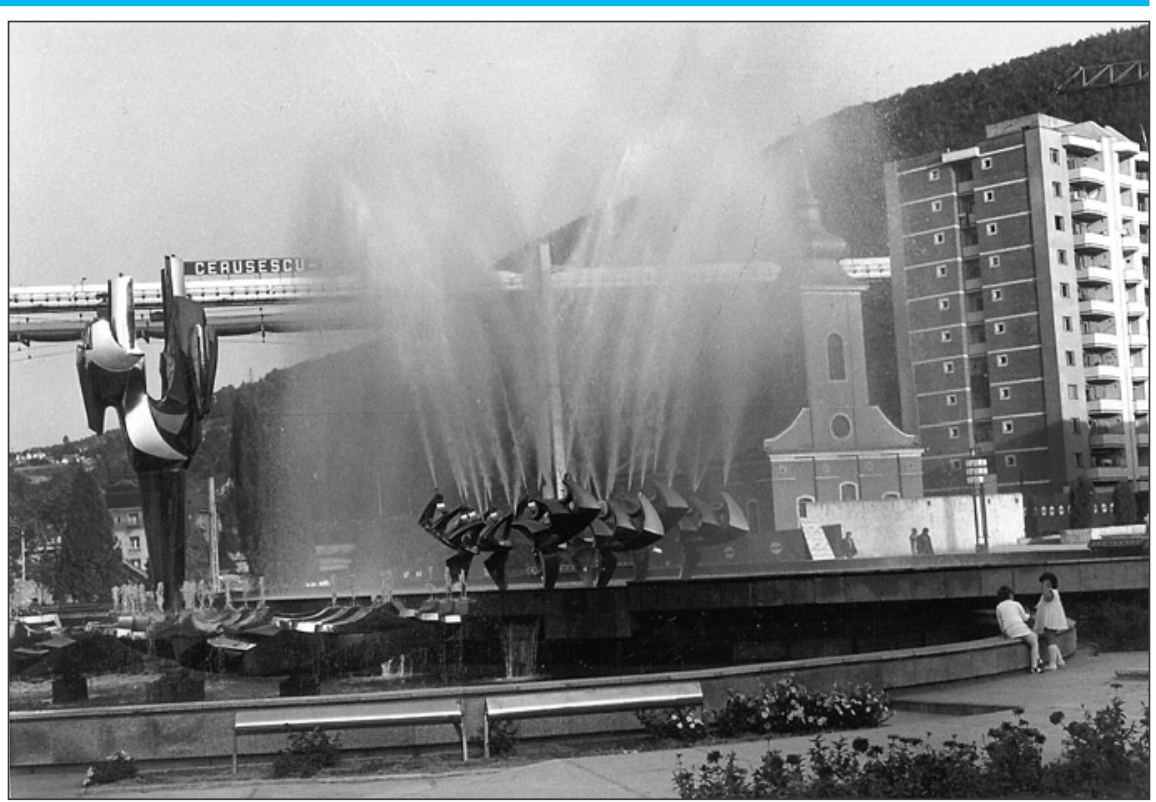

Plate 5: The main town square in Resita.

Mures-Tisa Euroregion - geoeconomical space of sustainable development (Timisoara: West University of Timisoara et al.) 341-8.

S. Balasa \& K.P. Dietzel eds. 1998, Regiunea economica Vest: concept de dezvoltare regionala (Timisoara: Editura Orizonturi Universitaire).

G. Ciuhandu et al. 2000, Concept strategic de devoltare economica si sociala a zonei Timisoara 2000 (Timisoara: Primaria).

V. Coifan ed. 1999, Strategia de dezvoltare economica a judetului Timis

(Timisoara: Editura Orizonturi Universitaire).

European Commission/Eurostat 1999, Regional GDP in the Central Euuropean Countries 1999 edition (data 1993-1996) (Luxembourg: Statistical Office of the European Communities).

Guvernul Romaniei \& Comisia Europeana Programul Phare 1997. Carta verde: politica de dezvoltare regionala in Romania (Bucharest: Guvernul Romaniei).

N. Hillinger 1998, 'Consideratii asupra proiectului de amenajare complexa a zonei dunarene a judetului Caras-Severin'. Revista Geografica 5, 121-3.

Larionescu, M., Rughinis, C. Radulescu, S. (1999), Cu ochii minerului: reforme mineritului in Romania (Bucharest: Editura Gnosis).

Nadejde, S. 1999, Methodologie d'analyse de l'espace rural selon les criteres de l'amenagement du territoire. In: V. Surd ed., Rural space and regional development (Cluj-Napoca: Editura Studia) 228-30.
Nica, N-A. 1999, Disadvantaged areas in the context of the rural development policy in Romania. In: V. Surd ed., Rural space and regional development (Cluj-Napoca: Editura Studia) 219-22.

A. Pal \& I. Nagy 1999, The economic relationships of the Hungarian-Romanian border region. In: C. Gruia et al. eds., Proceedings of the Regional Conference of Geography: DanubeCris-Mures-Tisa Euroregion - geoeconomical space of sustainable development (Timisoara: West University of Timisoara et al.) 369-85.

Popa, N. \& Sarbovan, C.A. 1999, Ethnicity in historical perspective. In: D. Turnock ed., Geographical essays on the Romanian Banat (Leicester: Leicester University Department of Geography) 150-61.

Ramboll Consultancy Group 1997, Profiles of the Romanian development regions (Bucharest: RCG for PHARE Programme, Regional Development Policy).

P. Tomic \& J. Romelic 1999, 'Geographic arrangement and organisation of industry in Banat': C. Gruia et al. eds. Proceedings of the Regional Conference of Geography: Danube-CrisMures-Tisa Euroregion - geoeconomical space of sustainable development (Timisoara: West University of Timisoara et al) 391-8.

S. Voiculescu 1999, 'The village of Izvin: a case study of prospective geography': V. Surd ed., Rural space and regional development (Cluj-Napoca: Editura Studia) 102-5. 